\title{
Gallbladder motility in children with celiac disease before and after gluten-free diet
}

\author{
Subhamoy Dasa, Sadhna B. Lal ${ }^{a}$, Vybhav Venkatesh ${ }^{a}$, Anish Bhattacharya ${ }^{b}$, Akshay Saxenac, B.R Thapa ${ }^{a}$, \\ Satya Vati Ranad
}

Postgraduate Institute of Medical Education and Research, Chandigarh, India

Abstract

\section{Introduction}

Celiac disease $(\mathrm{CD})$ is a lifelong, gluten-dependent autoimmune disorder characterized by an enteropathy. CD individuals may present with intestinal or extraintestinal

\section{aDivision of Pediatric Gastroenterology, Hepatology \& Nutrition (Subhamoy Das, Sadhna B. Lal, Vybhav Venkatesh, B.R Thapa); ${ }^{b}$ Department of Nuclear Medicine (Anish Bhattacharya); ${ }^{\mathrm{C} D e p a r t m e n t}$ of Radiodiagnosis (Akshay Saxena); ${ }^{\mathrm{d} D e p a r t m e n t ~ o f ~ G a s t r o e n t e r o l o g y ~}$ (Satya V Rana), Postgraduate Institute of Medical Education and Research, Chandigarh, India}

\section{Conflict of interest: None}

Correspondence to: Sadhna B. Lal, Professor \& Head, Division of Paediatric Gastroenterology, Hepatology \& Nutrition, Postgraduate Institute of Medical Education \& Research, Sector 12, Chandigarh 160012, India, e-mail: sadhnalal2014@gmail.com

Received 18 August 2020; accepted 2 November 2020; published online 5 February 2021

DOI: https://doi.org/10.20524/aog.2021.0593 manifestations, or may remain relatively asymptomatic [1]. The pathogenesis of CD is a dynamic process wherein mucosal disruption occurs in 3 stages. Increased intraepithelial lymphocytosis is followed by crypt hyperplasia, and lastly there is the destructive phase in which progressive villous atrophy leads to flattening of the mucosa. This mucosal damage and inflammation have been postulated to affect the gut-liver axis and also gut motility [2]. Besides other hepatobiliary disorders, impairment of gallbladder (GB) motility has been reported in adults with $\mathrm{CD}[3,4]$. This could be due to a reduced secretion of enteric hormones and/or a decreased GB sensitivity to them. The major trigger for GB contraction is cholecystokinin (CCK), a peptide hormone released from the mucosa of the upper small intestine after meals. A few studies of adult CD patients have documented that postprandial GB emptying is significantly reduced and that there are low postprandial levels of circulating CCK [4-6]. Furthermore, it has been reported that a gluten-free diet (GFD) reverses this GB dysmotility by promoting the secretion of CCK $[7,8]$. Studies using hepatobiliary scintigraphy (HBS) and ultrasonography (USG) demonstrated reduced GB ejection fraction (GBEF) in 
untreated adult celiacs $[3,6,8,9]$. Thus, most of the evidence is from studies in adult patients and there is a paucity of literature regarding GB motility in children with $\mathrm{CD}$, restricted to only a few case reports $[10,11]$. Hence, this study was conceptualized to evaluate $\mathrm{GB}$ motility in children with $\mathrm{CD}$ at baseline and after 6 months of a strict GFD.

\section{Patients and methods}

Fifty consecutive newly diagnosed children with $\mathrm{CD}$ attending the $\mathrm{CD}$ clinic of the Division of Pediatric Gastroenterology, Hepatology and Nutrition in a tertiary care hospital in North India from July 2015 to April 2016 were enrolled, after informed consent had been obtained from parents/primary caregivers. CD was diagnosed based on the revised criteria for diagnosis of CD 1990 [12]. Children suffering from any preexisting GB disease were excluded, as were those already on a GFD or suffering from any other systemic illness. The study was approved by the Institutional Ethics Committee. The radiation exposure for the patients from HBS was minimal and within the limits set by the Atomic Energy Regulatory Board. Assent from children was also sought wherever applicable.

\section{Study procedures}

Relevant history was obtained from the child and parents. The information was recorded in a predesigned proforma that included demographic information such as age, sex, address, socioeconomic background, and other details such as delay in diagnosis (calculated from time of first symptom onset to diagnosis), type of clinical presentation, anthropometry, clinical examination and investigation details (hemogram, liver function tests, thyroid function tests, vitamin D status, tissue transglutaminase [TTGA] antibodies, esophagogastroduodenoscopy findings, and biopsy findings). After enrolment, all the children underwent baseline USG and HBS for evaluation of GBEF. A meal containing at least $150 \mathrm{Kcal}$ and $10 \mathrm{~g}$ of fat is reported to be sufficient to induce GB contraction comparable to that induced by CCK analogs $[13,14]$. Hence, we used a standard fatty meal (SFM) containing $11 \mathrm{~g}$ of fat and $262 \mathrm{Kcal}(200 \mathrm{~mL}$ of commercially available sweetened buttermilk and a $20 \mathrm{~g}$ cheese slice). Those with a low GBEF on initial HBS were reevaluated by USG and HBS after 6 months of strict GFD.

\section{GFD}

All enrolled children and their families were counselled in detail regarding GFD at baseline and regularly thereafter during the study period to reinforce and ensure compliance. Initial GFD counselling was provided by a pediatric gastroenterology fellow (SD) in groups of up to 5 families, as well as individually to those needing further clarification. The patients were given an instruction sheet in their preferred language, detailing the foods allowed and not allowed. Queries from the children and parents were invited and answered at the end of each group counselling session. They were also given a mobile contact number for further clarification of doubts and apprehensions regarding the implementation of GFD. Patients and their parents were encouraged to use homemade GFD rather than commercial products. Dietary compliance was reinforced telephonically at regular intervals of 1 month and at every physical contact. Compliance was assessed by resolution of symptoms, standard dietary review at each outpatient visit and by repeat TTGA antibodies every 3 months. Standard dietary review consisted of details regarding the source of GFD, crosscontamination, willful and/or accidental ingestion of gluten (average number of instances per week). Patients and parents were also assessed regarding the accuracy of their knowledge of GFD and their ability to interpret labels.

\section{USG}

All the sonograms were performed by an experienced radiologist using a curved array probe $(2-5 \mathrm{MHz})$ on a Philips HD11 XE machine. The sonographic evaluation of the GB was performed after overnight fasting and $30 \mathrm{~min}$ after the SFM. The maximum length (L) and antero-posterior (AP) diameter were calculated on an image along the long axis of the GB, while the maximum transverse diameter (TR) was calculated from another image perpendicular to the previous one. All the measurements were made from inner wall to inner wall. The volume of the GB was calculated using the equation for a prolate ellipsoid, described by Dodds et al: Volume $=0.523 \times$ $\mathrm{L} \times \mathrm{AP} \times \mathrm{TR}[15]$.

\section{HBS}

The children underwent a Tc-99 labelled mebrofenin (BrIDA; bromo-2,4,6-trimethylacetanilido iminodiacetic acid) scan to study GB motility. The radiotracer, BrIDA, was administered intravenously in a dose of 0.5-3 mCi following standard guidelines. Serial static images pre- and post-SFM were acquired using a "large field of view" gamma camera equipped with a low-energy, general-purpose or highresolution collimator. The regions of interest were defined around the GB in pre- and post-meal images using a standard nuclear medicine software package. The GBEF was calculated from the GB time-activity curve as: $\mathrm{GBEF}(\%)=\left(\right.$ net GB cts ${ }_{\max }$ ) - (net GB cts min $\left._{\text {m }}\right) \times 100 /$ net GB cts ${ }_{\text {max }}$. A value of $<38 \%$ was used as a cutoff to label reduced GBEF $[16,17]$. The HBS and USG at baseline and after GFD were performed within 5 days of each other.

\section{Hydrogen breath test $\left(\mathrm{H}_{2} \mathrm{BT}\right)$}

All the children also underwent an $\mathrm{H}_{2} \mathrm{BT}$ at baseline with lactulose (10 g in $15 \mathrm{~mL}$ syrup) to determine the orocecal transit time (OCTT). All children were studied after an 
overnight fasting period of at least $12 \mathrm{~h}$ and after mouthwash with $1 \%$ chlorhexidine solution. None of the subjects had taken antibiotics/drugs likely to influence gastrointestinal motility for at least 4 weeks prior to the study. The end-expiratory hydrogen $\left(\mathrm{H}_{2}\right)$ concentration of the samples collected in duplicate in plastic bags was immediately measured using an SC Model Microlyser (Quintron, WI, USA) and expressed in parts per million (ppm). The time taken for a rise of $\mathrm{H}_{2}>10 \mathrm{ppm}$ above baseline after lactulose administration was considered as OCTT $[18,19]$.

\section{Statistical analysis}

Statistical analysis was performed using SPSS (Statistical Package for Social Sciences) software version 20.0 (SPSS Inc., Chicago, IL). As there are no large-scale studies even in adults regarding $\mathrm{GBEF}$ in $\mathrm{CD}$, assuming a prevalence of GBEF in CD was not possible. Hence a convenient sample of 50 children in a hospital-based setting was selected. The normality of the data was tested using the Shapiro-Wilk test. Categorical data were compared between groups (reduced and normal GBEF) using chi-square and Fisher exact tests, whereas continuous data were compared using the $t$-test. Comparison of GBEF parameters pre- and post-GFD was done using the paired $t$-test. Pearson correlation was used to determine the strength of association between 2 variables. All tests were 2 -tailed and a P-value of $<0.05$ was considered statistically significant.

\section{Results}

A total of 50 children (mean age $9 \pm 2.1$ years, $54 \%$ boys) were studied. Poor growth was the commonest symptom (82\%), followed by diarrhea (50\%), and abdominal pain (40\%). Twenty-five (50\%) children had non-classical CD. On anthropometry, objective evidence of poor growth, stunting (height more than 2 standard deviations below the median of the World Health Organization growth standards), was seen in $51 \%(n=26)$. Seven patients $(14 \%)$ had a positive family history. TTGA antibodies were elevated to more than 10 times the upper limit of normal in 47 (94\%). On biopsy, Marsh grade 3 changes were seen in 47 children (94\%) and the remaining had Marsh grade 2 changes. The baseline characteristics of the study population are depicted in Table 1 . After the institution of GFD, normalization of TTGA was seen in $86 \%$ of patients at 3 months and $98 \%$ at 6 months. Symptom resolution was achieved in all by 6 weeks and was maintained at 6 months post GFD institution.

Of the 50 children screened at baseline by Tc- 99 mebrofenin HBS, 16\% (8) had reduced GBEF. The baseline (pre-GFD) fasting, postprandial (after SFM) and percentage GB volume change of these children were recorded. Baseline USG for fasting and post prandial GB volumes was also performed in all children. After a strict GFD for a period of 6 months,
Table 1 Baseline characteristics of the study population $(n=50)$

\begin{tabular}{|c|c|}
\hline Characteristics & Value \\
\hline Age $($ mean \pm SD) & $9 \pm 2.1$ years \\
\hline Sex, n (\%) & Boys: 27 (54), Girls: 23 (46) \\
\hline Presenting symptoms, \% (n) & $\begin{array}{c}\text { Poor growth: } 82 \%(41) \\
\text { Diarrhea: } 50 \%(25) \\
\text { Abdominal pain: } 40 \%(20) \\
\text { Abdominal distension: } 34 \%(17) \\
\text { Constipation: } 12 \%(6) \\
\text { Vomiting: } 8 \%(4)\end{array}$ \\
\hline $\begin{array}{l}\text { Anthropometry }(\text { mean } \pm \text { SD) } \\
\text { Weight } z \text { score } \\
\text { Height } \mathrm{z} \text { score } \\
\text { BMI z score } \\
\text { Underweight, \% (n) } \\
\text { Stunting, \% (n) }\end{array}$ & $\begin{array}{c}-2.65 \pm 1.39 \\
-3.05 \pm 1.68 \\
-1.17 \pm 1.38 \\
12 \%(6) \\
51 \%(26)\end{array}$ \\
\hline Family history, \% (n) & $\begin{array}{c}\text { Celiac: } 14 \%(7) \\
\text { Thyroid disorders: } 4 \%(2) \\
\text { Diabetes: } 6 \%(3)\end{array}$ \\
\hline Signs, \% (n) & $\begin{array}{c}\text { Pallor: } 72 \%(36) \\
\text { Rickets: } 64 \%(32) \\
\text { Vitamin A deficiency: } 14 \%(7)\end{array}$ \\
\hline Serology, \% (n) & $\begin{array}{l}\text { TTGA > } 10 \text { ULN- } 94 \%(47) \\
\text { EMA positivity- } 94 \%(47)\end{array}$ \\
\hline $\begin{array}{l}\text { Hemogram }(\text { mean } \pm \text { SD }) \\
\text { Hemoglobin }(\mathrm{g} / \mathrm{dL}) \\
\text { Total leucocyte count }\left(\times 10^{9} / \mathrm{L}\right) \\
\text { Platelet count }\left(\times 10^{9} / \mathrm{L}\right)\end{array}$ & $\begin{array}{c}9.1 \pm 1.9 \\
7.0 \pm 1.9 \\
424 \pm 121\end{array}$ \\
\hline $\begin{array}{l}\text { Biochemistry }(\text { mean } \pm \text { SD) } \\
\text { Total bilirubin }(\mathrm{mg} / \mathrm{dL}) \\
\text { AST }(\mathrm{U} / \mathrm{L}) \\
\text { ALT }(\mathrm{U} / \mathrm{L}) \\
\text { ALP }(\mathrm{U} / \mathrm{L}) \\
\text { Serum total protein }(\mathrm{g} / \mathrm{dL}) \\
\text { Serum albumin }(\mathrm{g} / \mathrm{dL}) \\
\text { Vitamin D deficiency, \% (n) }\end{array}$ & $\begin{array}{c}0.8 \pm 0.3 \\
42.4 \pm 11 \\
37.8 \pm 8.4 \\
318.6 \pm 97.6 \\
7.5 \pm 0.6 \\
4 \pm 0.5 \\
78 \%(39)\end{array}$ \\
\hline $\begin{array}{l}\text { USG GBEF parameters }(\mathrm{mean} \pm \mathrm{SD}) \\
\text { Fasting volume }(\mathrm{mL}) \\
\text { Postprandial volume }(\mathrm{mL}) \\
\% \text { Volume change } \\
\text { Fasting wall thickness }(\mathrm{mm}) \\
\text { Postprandial wall thickness }(\mathrm{mm})\end{array}$ & $\begin{array}{c}11.5 \pm 4.6 \\
7.4 \pm 4.2 \\
35.6 \pm 26 \% \\
1.6 \pm 0.5 \\
2.0 \pm 0.5\end{array}$ \\
\hline $\begin{array}{l}\text { GBEF on Tc-99 mebrofenin HBS } \\
(\text { mean } \pm \text { SD })\end{array}$ & $63 \pm 23 \%$ \\
\hline
\end{tabular}

SD, standard deviation; TTGA, tissue transglutaminase antibody; ULN, upper limit of normal; EMA, endomysial antibody; AST, aspartate aminotransferase; $A L T$, alanine aminotransferase; ALP, alkaline phosphatase; USG,

ultrasonography; GBEF, gallbladder ejection fraction; HBS, hepatobiliary scintigraphy

repeat HBS and USG were performed to evaluate GBEF in the 8 children who had impaired GBEF by HBS at baseline. Apart from a significant improvement in GBEF on HBS (19\% to $74 \%$, $\mathrm{P}<0.001)$, the GBEF also improved significantly as assessed by USG parameters after GFD $(\mathrm{P}<0.001)$. The fasting $\mathrm{GB}$ volume reduced, with significant improvement in postprandial percentage GB volume change compared to baseline pre-GFD values (Table 2, Fig. 1). 
A subgroup analysis was done comparing children with normal and reduced GBEF (Table 3). Mean delay in diagnosis ( $6.5 \pm 2.0$ vs. $2.3 \pm 1.2$ years, $\mathrm{P}<0.001)$ and OCTT $(96.2 \pm 14$ vs. $56.1 \pm 12 \mathrm{~min}, \mathrm{P}<0.001)$ were significantly higher in children with reduced GBEF. Other clinical and biochemical parameters did not differ significantly between the 2 subgroups.

The delay in diagnosis had a significant negative correlation with baseline GBEF on HBS $(r=-0.5, \mathrm{P}<0.001)$ and percentage postprandial GB volume change on USG $(\mathrm{r}=-0.3, \mathrm{P}<0.01)$, and a significant positive correlation with OCTT $(r=0.6, \mathrm{P}<0.001)$, implying that as the delay in diagnosis increases, GBEF decreases and OCTT increases. Similarly, OCTT and GBEF on HBS showed a significant negative correlation $(r=-0.6$, $\mathrm{P}<0.001$ ) (Fig. 2). Representative HBS images from one patient are shown in Fig. 3.

\section{Discussion}

A wide spectrum of hepatobiliary disorders due to alterations in the complex gut-liver axis has been described in $\mathrm{CD}$, which includes asymptomatic elevation of liver enzymes,

Table 2 Comparison of gallbladder ejection fraction parameters on ultrasonography and hepatobiliary scintigraphy pre- and post-GFD in children with low gallbladder ejection fraction at baseline $(n=8)$

\begin{tabular}{lccc}
\hline Parameters & Pre-GFD & Post-GFD & P-value \\
\hline USG GB volume in $\mathrm{mL}$ & & & \\
(mean \pm SD) & & & \\
$\quad$ Fasting & $10.2 \pm 2.6$ & $5.7 \pm 1.4$ & 0.002 \\
$\quad$ Postprandial & $7.6 \pm 1.5$ & $2.7 \pm 0.6$ & 0.001 \\
\% Volume change & $24 \pm 16.5 \%$ & $52 \pm 10.5 \%$ & 0.007 \\
GBEF on HBS (\%) & $19 \pm 13 \%$ & $74 \pm 12 \%$ & 0.001 \\
(mean \pm SD) & & & \\
\hline
\end{tabular}

GFD, gluten-free diet; USG, ultrasonography; GB, gallbladder; GBEF, gallbladder ejection fraction; HBS, hepatobiliary scintigraphy celiac hepatitis, nonalcoholic fatty liver disease, autoimmune hepatitis, primary biliary cirrhosis, etc. [2,20-22]. Apart from these, motility disorders have also been reported. Various motility disorders of esophagus, stomach, colon and GB have been reported in patients with CD [23,24].

$\mathrm{GB}$ dysfunction in $\mathrm{CD}$ is explained by impaired CCK secretion from the damaged small bowel mucosa [3-5]. In a study by Benini et al, GB motility was assessed by USG and the authors found that the fasting and postprandial GB volumes were significantly higher in patients with $\mathrm{CD}$ compared to controls [7]. Similar results were reported by Fraquelli et al, in a cohort of 10 adults with CD; they also found that GFD reversed these abnormalities [6]. Brown et al [3] and LowBeer et al [4] used HBS for measuring GBEF and found that patients with CD had reduced GBEF. This GB dysmotility, if left untreated, may predispose to gallstone disease and associated complications [25-27]. It has been observed that, in addition to GB dysmotility in $\mathrm{CD}$, biliary lipid secretion is also increased, leading to supersaturation of bile and formation of gallstones $[28,29]$. In one study, the prevalence of gallstone disease was $20 \%$ in adult celiacs [30].

GB dysmotility in children with $\mathrm{CD}$ remains an uninvestigated area. A study by Nousia et al demonstrated exocrine pancreatic dysfunction secondary to decreased CCK in children with CD, reversible with GFD [31]. In our study, 8 children (16\%) had a low GBEF at diagnosis. These children had a significantly greater delay in diagnosis (duration of illness prior to diagnosis) compared to children with a normal GBEF ( $6.5 \pm 2.0$ vs. $2.3 \pm 1.2$ years, $\mathrm{P}<0.001)$. Furthermore, the duration of illness had significant negative correlation with GBEF on HBS $(r=-0.5, \mathrm{P}<0.001)$ and USG $(\mathrm{r}=-0.3, \mathrm{P}<0.01)$, implicating a delay in diagnosis as an important factor leading to significant impairment in GB motility. Delayed diagnosis has been shown to adversely affect long-term outcomes in patients with CD [32-34].

Another important observation in our study is the presence of small bowel dysmotility, along with GB dysmotility, in

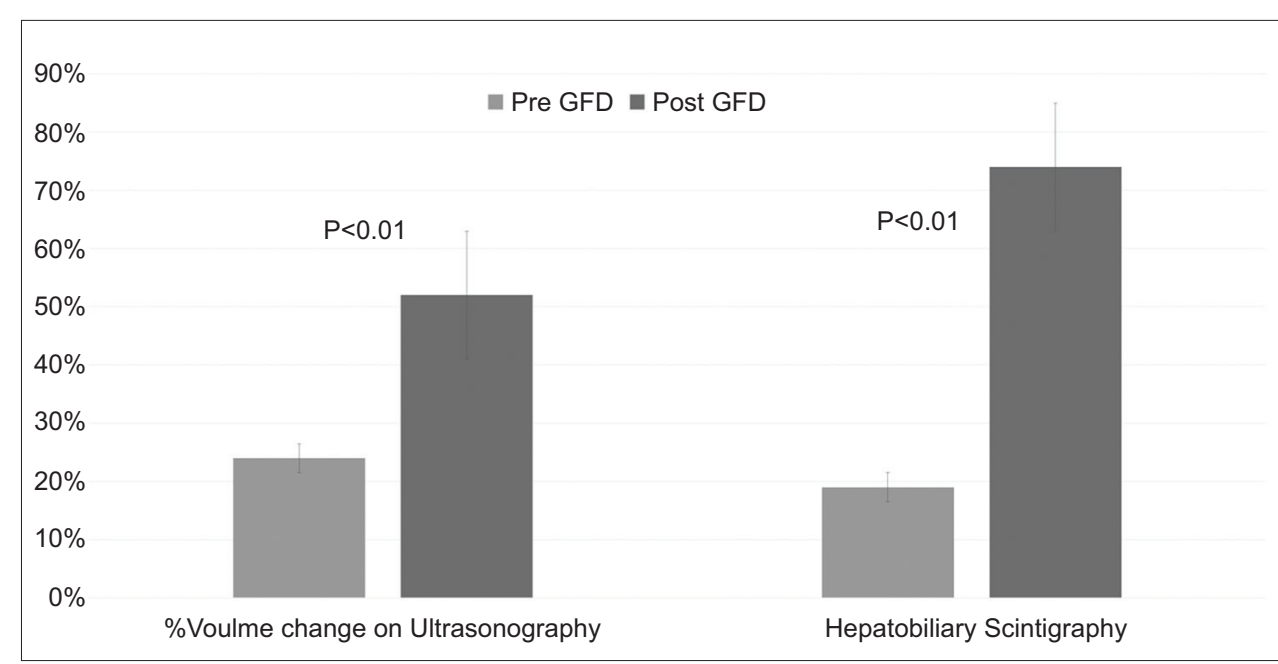

Figure 1 Comparison of gallbladder ejection fraction (GBEF) by ultrasonography and Tc-99 mebrofenin hepatobiliary scintigraphy pre and post gluten-free diet (GFD) in children with reduced GBEF at baseline 
Table 3 Comparison of baseline characteristics between normal and low GBEF subgroups

\begin{tabular}{|c|c|c|c|}
\hline Characteristics & Normal GBEF $(n=42)$ & Low GBEF $(\mathrm{n}=8)$ & P-value \\
\hline Age in years $($ mean $\pm S D)$ & $9.07 \pm 2.0$ & $8.8 \pm 2.8$ & 0.8 \\
\hline Boys, n (\%) & $22(52.3 \%)$ & $5(62.5 \%)$ & 0.7 \\
\hline $\begin{array}{l}\text { Presenting symptoms, \% (n) } \\
\text { Poor growth } \\
\text { Diarrhea } \\
\text { Abdominal pain } \\
\text { Abdominal distension } \\
\text { Constipation } \\
\text { Vomiting }\end{array}$ & $\begin{array}{l}90.5 \%(38) \\
50 \%(21) \\
45.2 \%(19) \\
28.5 \%(12) \\
14.2 \%(6) \\
9.5 \%(4)\end{array}$ & $\begin{array}{l}37.5 \%(3) \\
50 \%(4) \\
12.5 \%(1) \\
62.5 \%(5) \\
0(0) \\
0(0)\end{array}$ & $\begin{array}{l}0.03 \\
1.0 \\
0.1 \\
0.1 \\
0.5 \\
1.0\end{array}$ \\
\hline Delay in diagnosis in years (mean $\pm \mathrm{SD}$ ) & $2.3 \pm 1.2$ & $6.5 \pm 2.0$ & 0.001 \\
\hline $\begin{array}{l}\text { Anthropometry }(\text { mean } \pm \text { SD) } \\
\text { Weight } z \text { score } \\
\text { Height z score } \\
\text { BMI z score } \\
\text { Underweight, \% (n) } \\
\text { Stunting, \% (n) }\end{array}$ & $\begin{array}{l}-2.61 \pm 1.31 \\
-3.05 \pm 1.70 \\
-1.16 \pm 1.38 \\
12 \%(5) \\
50 \%(21)\end{array}$ & $\begin{array}{c}-2.85 \pm 1.86 \\
-3.05 \pm 1.71 \\
-1.24 \pm 1.51 \\
12.5 \%(1) \\
62.5 \%(5)\end{array}$ & $\begin{array}{l}0.6 \\
0.9 \\
0.8 \\
1.0 \\
0.7\end{array}$ \\
\hline $\begin{array}{l}\text { Hemogram }(\text { mean } \pm \mathrm{SD}) \\
\text { Hemoglobin }(\mathrm{g} / \mathrm{dL}) \\
\text { Total leucocyte count }\left(\times 10^{9} / \mathrm{L}\right) \\
\text { Platelet count }\left(\times 10^{9} / \mathrm{L}\right)\end{array}$ & $\begin{array}{c}9.2 \pm 1.9 \\
6.9 \pm 1.8 \\
414 \pm 121\end{array}$ & $\begin{array}{c}8.8 \pm 2.2 \\
7.3 \pm 2.8 \\
479 \pm 112\end{array}$ & $\begin{array}{c}0.5 \\
0.60 .1\end{array}$ \\
\hline $\begin{array}{l}\text { Biochemistry }(\text { mean } \pm \mathrm{SD}) \\
\text { Total bilirubin }(\mathrm{mg} / \mathrm{dL}) \\
\text { AST }(\mathrm{U} / \mathrm{L}) \\
\text { ALT }(\mathrm{U} / \mathrm{L}) \\
\text { ALP }(\mathrm{U} / \mathrm{L}) \\
\text { Serum total protein }(\mathrm{g} / \mathrm{dL}) \\
\text { Serum albumin }(\mathrm{g} / \mathrm{dL}) \\
\text { Vitamin D deficiency, \% (n) }\end{array}$ & $\begin{array}{c}0.8 \pm 0.32 \\
41 \pm 10 \\
38 \pm 8 \\
323 \pm 103 \\
7.5 \pm 0.6 \\
3.9 \pm 0.5 \\
78.5 \%(33)\end{array}$ & $\begin{array}{c}0.8 \pm 0.35 \\
48 \pm 13.5 \\
38 \pm 11 \\
293 \pm 63 \\
7.5 \pm 0.5 \\
4.1 \pm 0.6 \\
75 \%(6)\end{array}$ & $\begin{array}{c}0.9 \\
0.1 \\
0.9 \\
0.4 \\
0.80 .4 \\
1.0\end{array}$ \\
\hline $\begin{array}{l}\text { USG GBEF parameters (mean } \pm \text { SD) } \\
\text { Fasting volume }(\mathrm{mL}) \\
\text { Postprandial volume }(\mathrm{mL}) \\
\% \text { Volume change } \\
\text { Fasting wall thickness }(\mathrm{mm}) \\
\text { Postprandial wall thickness }(\mathrm{mm})\end{array}$ & $\begin{array}{l}11.8 \pm 4.9 \\
7.4 \pm 4.6 \\
38 \pm 27 \% \\
1.6 \pm 0.5 \\
2.1 \pm 0.6\end{array}$ & $\begin{array}{c}10.2 \pm 2.6 \\
7.6 \pm 1.5 \\
24 \pm 16.5 \% \\
1.4 \pm 0.2 \\
1.8 \pm 0.3\end{array}$ & $\begin{array}{c}0.30 .9 \\
0.06 \\
0.30 .1\end{array}$ \\
\hline GBEF on Tc-99 mebrofenin HBS (mean \pm SD) & $71 \pm 13 \%$ & $19 \pm 13 \%$ & 0.001 \\
\hline OCTT in min $($ mean \pm SD $)$ & $56.1 \pm 12$ & $96.2 \pm 14$ & 0.001 \\
\hline
\end{tabular}

SD, standard deviation; AST, aspartate aminotransferase; ALT, alanine aminotransferase; ALP, alkaline phosphatase; USG, ultrasonography; GBEF, gallbladder ejection fraction; HBS, hepatobiliary scintigraphy; OCTT, orocecal transit time

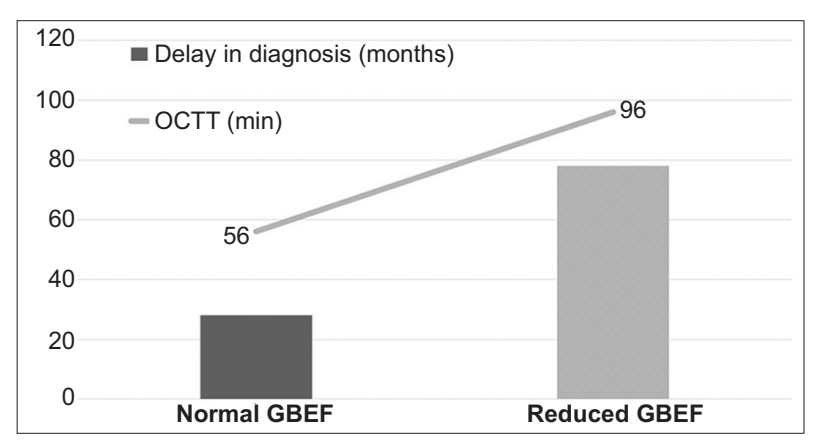

Figure 2 Comparison of delay in diagnosis and orocecal transit time (OCTT) between normal and reduced gallbladder ejection fraction (GBEF) subgroups
CD children with reduced GBEF. Increased OCTT has been described in adults with CD in various studies $[7,18,35,36]$. It is attributed to alterations in the complex neurohormonal regulatory mechanism of gut motility by the damaged intestinal mucosa [24,37]. Increased OCTT has been implicated as a predisposing factor to the development of small intestinal bacterial overgrowth (SIBO) in patients with CD [38,39]. OCTT was significantly higher in children with reduced GBEF compared to those with normal GBEF in our study $(96.2 \pm 14$ vs. $56.1 \pm 12 \mathrm{~min}, \mathrm{P}<0.001)$. Furthermore, OCTT also had a significant negative correlation with GBEF on HBS, suggesting that GBEF decreases as OCTT increases. These findings suggest a generalized gastrointestinal hypomotility involving both GB and small bowel in untreated children with CD. 


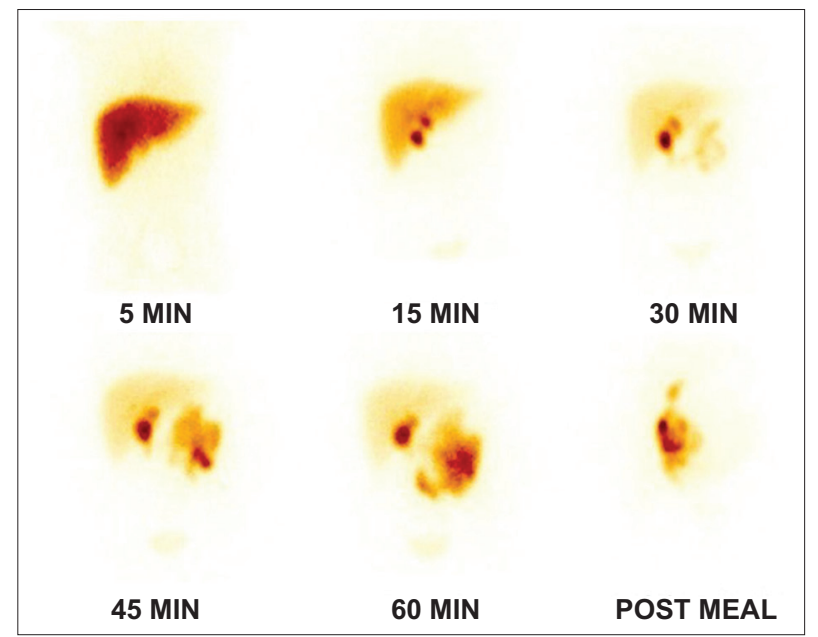

Figure 3 Representative hepatobiliary scintigraphy image of a child post gluten-free diet. Sequential static images of the abdomen in the anterior projection following intravenous injection of Tc- $99 \mathrm{~m}$ mebrofenin from 5-60 min and then after a fatty meal. There is uniform tracer uptake in both lobes of the liver, followed by unobstructed drainage through the biliary tract into the bowel. The gallbladder is visualized at $15 \mathrm{~min}$ and continues to fill up to $60 \mathrm{~min}$. Following a fatty meal, there is rapid emptying of the gallbladder in the post-meal image (ejection fraction 51\%)

After ensuring GFD for 6 months, the subgroup of children with reduced GBEF had significant improvement in GBEF parameters as assessed by both HBS (increase to 74\% from $19 \%$ ) and USG (increase to 52\% from 24\%), indicating that a GFD can reverse the abnormalities of GB motility in children with CD. GFD results in the reconstitution of normal villous architecture with return of normal CCK cell function, leading to an improvement in GB motility.

To the best of our knowledge, this is the first study in children with $\mathrm{CD}$ to evaluate GB dysmotility and the effect of GFD upon it. We used both HBS and USG for evaluating GBEF; however, because of the small sample size, we cannot comment on the usefulness of one modality versus the other. We could not implicate any clinical/biochemical risk factors to predict GB dysmotility in children with CD. In addition, retrospectively, we should have also planned a gastric emptying study, to help us comment better on the possible mechanisms of prolonged OCTT. TTGA may also not be the ideal tool to assess compliance, with the possibility of falsenegative results despite gluten consumption. However, there was a clear-cut clinical resolution of other symptoms in our patients.

To conclude, GB dysmotility can occur in children with $\mathrm{CD}$, especially if the diagnosis is delayed, but it is reversible with adherence to GFD. GB hypomotility may translate into gallstone disease, with its related complications, in adulthood if $\mathrm{CD}$ is left untreated. It can coexist with a delayed small-bowel transit, which may predispose these children to SIBO later on. Early diagnosis of CD and prompt institution of GFD would prevent the occurrence of such morbidity and improve the quality of life in children with CD.

\section{Summary Box}

\section{What is already known:}

- Gallbladder dysfunction has been described in adult celiac disease

- Hepatobiliary scintigraphy and ultrasonography can be used to assess gallbladder contractility

What the new findings are:

- Celiac disease in children may be associated with impaired gallbladder contractility

- Gallbladder dysfunction improved with a glutenfree diet

- Gallbladder dysfunction in children was associated with slower intestinal transit

\section{References}

1. Gujral N, Freeman HJ, Thomson AB. Celiac disease: prevalence, diagnosis, pathogenesis and treatment. World J Gastroenterol 2012;18:6036-6059.

2. Hoffmanová I, Sánchez D, Tučková L, Tlaskalová-Hogenová H. Celiac disease and liver disorders: from putative pathogenesis to clinical implications. Nutrients 2018;10:892.

3. Brown AM, Bradshaw MJ, Richardson R, Wheeler JG, Harvey RF. Pathogenesis of the impaired gall bladder contraction of coeliac disease. Gut 1987;28:1426-1432.

4. Low-Beer TS, Harvey RF, Davies ER, Read AF. Abnormalities of serum cholecystokinin and gallbladder emptying in celiac disease. N Engl J Med 1975;292:961-963.

5. Masclee AA, Jansen JB, Driessen WM, Geuskens LM, Lamers CB. Gallbladder sensitivity to cholecystokinin in coeliac disease. Correlation of gallbladder contraction with plasma cholecystokinin-like immunoreactivity during infusion of cerulein. Scand J Gastroenterol 1991;26:1279-1284.

6. Fraquelli M, Bardella MT, Peracchi M, Cesana BM, Bianchi PA, Conte D. Gallbladder emptying and somatostatin and cholecystokinin plasma levels in celiac disease. Am J Gastroenterol 1999;94:1866-1870.

7. Benini F, Mora A, Turini D, et al. Slow gallbladder emptying reverts to normal but small intestinal transit of a physiological meal remains slow in celiac patients during gluten-free diet. Neurogastroenterol Motil 2012;24:100-107, e79-e80.

8. Maton PN, Selden AC, Fitzpatrick ML, Chadwick VS. Defective gallbladder emptying and cholecystokinin release in celiac disease. Reversal by gluten-free diet. Gastroenterology 1985;88:391-396.

9. Delamarre J, Capron JP, Joly JP, et al. [Gallbladder atony and celiac disease in adults. Radiographic and echographic study of 15 cases]. J Radiol 1984;65:133-136.

10. González JA, González JB, Crespo MJ, Sancho CI. Acute gallbladder distension and recurrent small bowel intussusception in a child with celiac disease. J Pediatr Gastroenterol Nutr 1998;27:444-445.

11. Sinha CK, Haider N, Zaw W, Nour S. Recurrent intussusception, coeliac disease and cholelithiasis: A unique combination. J Indian Assoc Pediatr Surg 2007;12:221-223.

12. Revised criteria for diagnosis of coeliac disease. Report of Working Group of European Society of Paediatric Gastroenterology and 
Nutrition. Arch Dis Child 1990;65:909-911.

13. Kakhki VRD, Zakavi SR, Davoudi Y. Normal values of gallbladder ejection fraction using $99 \mathrm{mTc}$-sestamibi scintigraphy after a fatty meal formula. J Gastrointestin Liver Dis 2007;16:157-161.

14. Krishnamurthy GT, Brown PH. Comparison of fatty meal and intravenous cholecystokinin infusion for gallbladder ejection fraction. J Nucl Med 2002;43:1603-1610.

15. Dodds W, Groh W, Darweesh R, Lawson T, Kishk S, Kern M. Sonographic measurement of gallbladder volume. AJR Am J Roentgenol 1985;145:1009-1011.

16. Ziessman HA, Tulchinsky M, Lavely WC, et al. Sincalidestimulated cholescintigraphy: a multicenter investigation to determine optimal infusion methodology and gallbladder ejection fraction normal values. J Nucl Med 2010;51:277-281.

17. Ziessman HA. Hepatobiliary scintigraphy in 2014. J Nucl Med 2014;55:967-975.

18. Rana SV, Sharma S, Sinha SK, Prasad KK, Bhasin DK, Singh K. Orocecal transit time in patients with celiac disease from North India: a case control study. Trop Gastroenterol 2008;29:98-100.

19. Rana SV, Malik A. Hydrogen breath tests in gastrointestinal diseases. Indian J Clin Biochem 2014;29:398-405.

20. Anania C, De Luca E, De Castro G, Chiesa C, Pacifico L. Liver involvement in pediatric celiac disease. World J Gastroenterol 2015;21:5813-5822.

21. Marciano F, Savoia M, Vajro P. Celiac disease-related hepatic injury: Insights into associated conditions and underlying pathomechanisms. Dig Liver Dis 2016;48:112-119.

22. Rubio-Tapia A, Murray JA. The liver in celiac disease. Hepatology 2007;46:1650-1658.

23. Elli L, Bardella MT. Motility disorders in patients with celiac disease. Scand J Gastroenterol 2005;40:743-749.

24. Usai-Satta P, Oppia F, Lai M, Cabras F. Motility disorders in celiac disease and non-celiac gluten sensitivity: The impact of a glutenfree diet. Nutrients 2018;10:1705.

25. Freeman HJ. Hepatobiliary and pancreatic disorders in celiac disease. World J Gastroenterol 2006;12:1503-1508.

26. Freeman H, Lemoyne M, Pare P. Coeliac disease. Best Pract Res Clin Gastroenterol 2002;16:37-49.

27. DiMagno EP, Go WL, Summerskill WH. Impaired cholecystokininpancreozymin secretion, intraluminal dilution, and maldigestion of fat in sprue. Gastroenterology 1972;63:25-32.

28. Freeman HJ. Clinical spectrum of biopsy-defined celiac disease in the elderly. Can J Gastroenterol 1995;9:42-46.

29. Vuoristo M, Miettinen TA. Increased biliary lipid secretion in celiac disease. Gastroenterology 1985;88:134-142.

30. Wang HH, Liu M, Li X, Portincasa P, Wang DQ. Impaired intestinal cholecystokinin secretion, a fascinating but overlooked link between coeliac disease and cholesterol gallstone disease. Eur J Clin Invest 2017;47:328-333.

31. Nousia-Arvanitakis S, Fotoulaki M, Tendzidou K, Vassilaki C, Agguridaki C, Karamouzis M. Subclinical exocrine pancreatic dysfunction resulting from decreased cholecystokinin secretion in the presence of intestinal villous atrophy. J Pediatr Gastroenterol Nutr 2006;43:307-312.

32. Corrao G, Corazza GR, Bagnardi V, et al; Club del Tenue Study Group. Mortality in patients with coeliac disease and their relatives: a cohort study. Lancet 2001;358:356-361.

33. Norström F, Lindholm L, Sandström O, Nordyke K, Ivarsson A. Delay to celiac disease diagnosis and its implications for healthrelated quality of life. BMC Gastroenterol 2011;11:118.

34. Rubio-Tapia A, Kyle RA, Kaplan EL, et al. Increased prevalence and mortality in undiagnosed celiac disease. Gastroenterology 2009;137:88-93.

35. Spiller RC, Lee YC, Edge C, et al. Delayed mouth-caecum transit of a lactulose labelled liquid test meal in patients with steatorrhoea caused by partially treated coeliac disease. Gut 1987;28:1275-1282.

36. Chiarioni G, Bassotti G, Germani U, et al. Gluten-free diet normalizes mouth-to-cecum transit of a caloric meal in adult patients with celiac disease. Dig Dis Sci 1997;42:2100-2105.

37. Pinto-Sanchez MI, Bercik P, Verdu EF. Motility alterations in celiac disease and non-celiac gluten sensitivity. Dig Dis 2015;33:200-207.

38. Tursi A, Brandimarte G, Giorgetti G. High prevalence of small intestinal bacterial overgrowth in celiac patients with persistence of gastrointestinal symptoms after gluten withdrawal. Am J Gastroenterol 2003;98:839-843.

39. Rubio-Tapia A, Barton SH, Rosenblatt JE, Murray JA. Prevalence of small intestine bacterial overgrowth diagnosed by quantitative culture of intestinal aspirate in celiac disease. J Clin Gastroenterol 2009;43:157-161. 